\title{
Evaluation and Accreditation System of External Internship Tutors - SEATPE
}

\begin{abstract}
María Adela Valero Aleixandre ${ }^{1}$, Miguel Ángel Barberá Gregori², Alfredo Pérez Boullosa $^{3}$, Yolanda Montoro Sánchez ${ }^{2}$, María Ridocci Quiles ${ }^{2}$

${ }^{1}$ Pharmacy and Pharmaceutical Technology and Parasitology Department, University of Valencia, Spain, ${ }^{2}$ Internships' Department, Foundation-Company of the University of Valencia (ADEIT), Spain, ${ }^{3}$ Research Methods and Diagnosis in Education Department, University of Valencia, Spain.
\end{abstract}

\begin{abstract}
The University of Valencia has implemented since 2012 an Evaluation and Accreditation System of External Internships Tutors (SEATPE) through its University-Company Foundation, ADEIT, under the direction of the Vice Chancellor for Employment and Formative Programs. The main objectives of this system are to improve the quality of tutoring of external internships implementing mechanisms to recognize the good work of the tutors and increase the commitment of companies and entities with the practical training of our students. It is aimed at the two profiles of tutors: academics and companies. The tutors who access the SEATPE obtain a "Quality Mention" in the case of the academic tutor and an "Accreditation" in the case of the company tutor. So far we have made five calls and 500 internship tutors have obtained their accreditation or mention of quality.
\end{abstract}

Keywords: Quality; evaluation; tutor's training; external internships; practicum; tutoring. 


\section{Introduction}

The University of Valencia has developed in recent years a series of actions and programs aimed at improving the quality of its external internships. In this context, during 2012 we designed the Evaluation and Accreditation System of External Internship Tutors (hereinafter SEATPE), funded by the Ministry of Education, Culture and Sports directed by the Vice Chancellor for Language Studies and Policy and which was promoted by its UniversityCompany Foundation of Valencia (hereinafter ADEIT) as an organization responsible for the management of its external academic internships, with the objective of establishing a framework for improving the quality of external internship tutorials, implementing mechanisms to recognize the good work of the internship tutors and increase the commitment of companies and entities with the practical training of our students.

One of the pillars on which the system is based is the confluence in the formative actions of the two profiles of tutors, company or entity and academics. The program is taught in a personalized way and with a necessary face-to-face component, which is one of the elements most valued by the participants in all the editions celebrated. 7,500 people tutor each year: 6,300 belong to the company or entity and 1,200 are academics. A maximum of 150 people access each SEATPE call, so we are looking for alternatives to offer it to a greater number of tutors.

In general, the SEATPE is mainly aimed at people with experience in tutoring external university internships and it is structured in two phases. In the first, a training course on Teaching and management of external internship tutoring (level A) is taught following a quality model of the validated and proven tutoring. Once this has been completed, the workshop for the preparation of an external internship tutoring project (level B) in which the presentation of an individual internship tutoring project is evaluated is carried out in the second phase.

After passing both levels, an Accreditation is obtained, if you are a company or entity professional, or a Quality Mention if you are an academic teacher, which is issued jointly by ADEIT and the University of Valencia.

\section{Quality model of external internship tutoring}

We have defined six dimensions that make up the quality model of the internship tutoring: 1 .

Training program; 2. Tutorial's Organization; 3. Human Resources; 4. Tutoring development; 5. Results and 6. Quality Assurance.

For each of the dimensions we have identified some criteria, as well as the most relevant aspects that define them and are necessary to consider and assess in order to achieve a quality external practice tutoring. 
The dimensions and quality criteria that make up the model have been the result of a review and validation process by three groups of experts, both internal to the university institution itself, as professionals from various fields of the productive world and integrated into organizations with extensive experience in collaboration with the practices of the University of Valencia.

In the quality model of mentoring we have identified four essential moments of mentoring that have modeled the content of the two training actions contemplated in the SEATPE and they are described in the following section.

\section{Internship Tutors' Training}

As we have commented previously, SEATPE contemplates the participation and overcoming of two training actions that correspond to two levels of competence and perform consecutively. In the first level, knowledge about the quality model of the tutoring is acquired and in the second level it is applied to a specific tutoring project.

To deliver the two training actions we have a teaching team consisting of ten people, half with an academic profile and the other half with a company or entity profile and who are experts and accredited by the system.

\subsection{Level A Course "Teaching and Management of an External Internship Tutoring"}

The objectives of this course are first of all to show the elements involved in external internships and the main functions performed by the academic tutor and the company tutor; secondly, to provide tools and documents that facilitate the performance of a good internship tutoring; and thirdly, to promote the exchange of experiences between the academic tutor and the Company tutor.

It lasts 20 hours and uses a blended methodology: 10 hours of online training (virtual classroom) and 10 hours of in-person lessons.

It is structured in five didactic units that correspond to an initial, external internships and tutorials, and four that respond to the four essential moments of the tutoring: Tutoring Preparation; Student preparation; Internship Following-up and Internship Evaluation.

Among the face-to-face actions, the holding of the two in-person workshops stands out. These workshops are held in the middle and end of the course and they study, through group dynamics, activities on the units treated. 


\subsection{Level B Course "Workshop for the elaboration of an external internships tutoring project"}

The course is aimed at those tutors who have passed the level A course and consists of the design of an internship tutoring program, adjusted to the quality model addressed in course A. To this end, a guide for its preparation is provided, which It is completed with the followup and personalized attention carried out by the teaching team.

It is taught in the online mode with a duration of 30 hours, and in which the tutor prepares his individual tutoring project with a student or a group of students, as long as the internship is carried out in the same company or institution and with a single company tutor and a single academic tutor.

As a result, each tutor obtains a personalized quality tutoring project, which can serve as a framework for their tutorial work, either from the perspective of the company or from the academic.

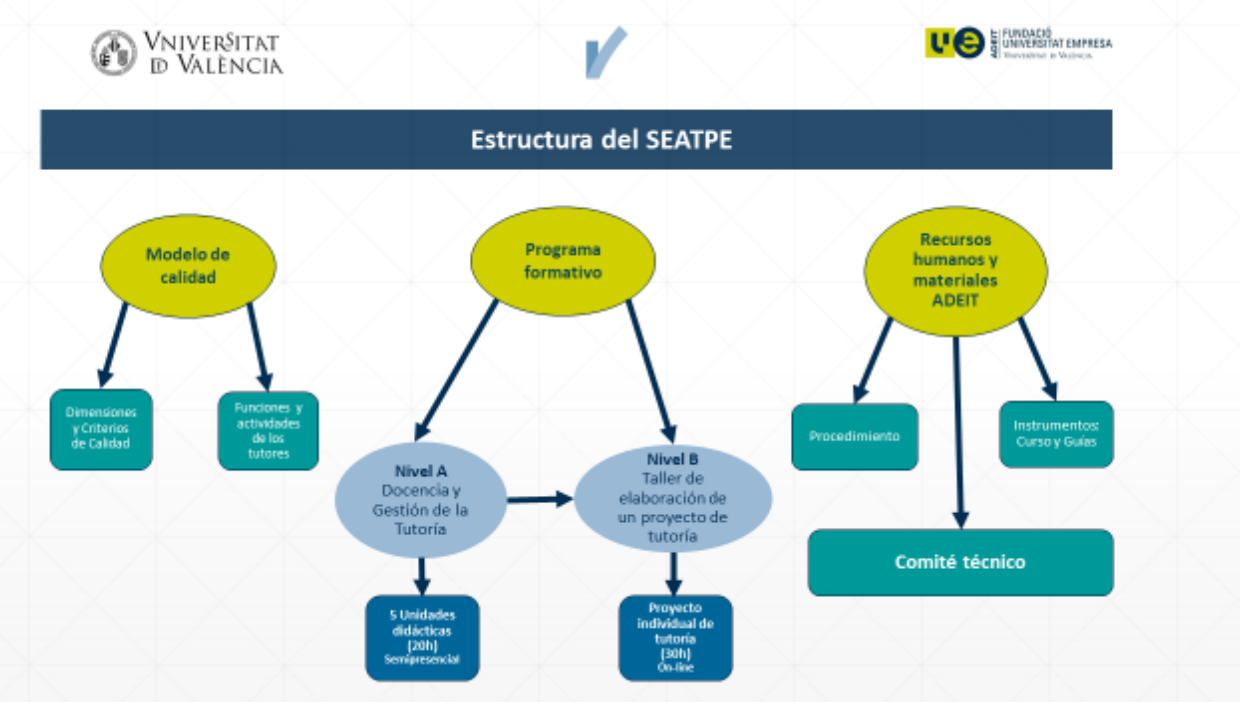

Figure 1. SEATPE general scheme.

Source: own elaboration (2020).

\section{Results}

This system of training and accreditation of tutors of the University of Valencia (SEATPE) promoted by its Foundation (ADEIT) has been applied in five calls in 2012, 2016, 2017, 2018 and 2019, and 499 tutors have obtained their accreditation or mention of quality internship: 266 company or entity tutors and 233 academic tutors. 
Table 1. SEATPE participation evoluction.

\begin{tabular}{lccc}
\hline AÑO & TA & TE & TOTAL \\
\hline 2012 & 57 & 47 & $\mathbf{1 0 4}$ \\
$2016-$ II & 51 & 44 & $\mathbf{9 5}$ \\
$2016-$ PII & 13 & 10 & $\mathbf{2 3}$ \\
2017 & 32 & 47 & $\mathbf{7 9}$ \\
2018 & 36 & 40 & $\mathbf{7 6}$ \\
2019 & 44 & 78 & $\mathbf{1 2 2}$ \\
TOTAL & $\mathbf{2 3 3}$ & $\mathbf{2 6 6}$ & $\mathbf{4 9 9}$ \\
\hline
\end{tabular}

TE: Company or entity tutor; TA: academic tutor. Source: own elaboration (2020).

The degree of satisfaction with the program is very high, so we emphasize that, globally, $90 \%$ of the participants think that the training has been useful and $93 \%$ recommend it to other tutors.

Table 2. Satisfaction degree of the participants in the five editions.

\begin{tabular}{lc}
\hline Item & $\begin{array}{c}\text { Average Rating } \\
\text { about 7 }\end{array}$ \\
\hline Training process & 6,1 \\
Training materials & 6,3 \\
Teaching performance of teachers & 6,5 \\
Tutorials & 6,6 \\
Course Environment & 5,4 \\
Complementary services & 6,4 \\
Face-to-face sessions & 6,4 \\
Global Source: elaboración propia (2020). & 6,2 \\
\hline
\end{tabular}

The program manifests itself as important and necessary to offer to our professionals and teachers who participate as tutors of external internships an instrument of communication, recognition, training and accreditation.

The next SEATPE call is scheduled for the second half of this year 2020. 


\section{References}

Barberá Gregori, M.A., Montoro Sánchez, y Pérez Boullosa, A. (2017). Como evaluar la calidad de una tutoría de prácticas externas. En Muñoz Carril, P.C., González Sanmamed, M., Raposo-Rivas, M., Erkizia Olaizola, A., Cebrián de la Serna, M., Pérez-Abellás, A. Barberá Gregori, M.A., Canet Velez, O., Zabalza, M. Á. (Coords.) Recursos para un Prácticum de Calidad, (págs. 446-457). Santiago de Compostela: Andavira.

Barberá Gregori, M.A. (2015). Las Prácticas en Empresas en la Universidad: Diseño y Validación de un Modelo de Gestión de la Calidad. Tesis doctoral. Departamento de Métodos de Investigación y Diagnóstico en Educación. Universidad de Valencia. Disponible en "URL” http://roderic.uv.es/handle/10550/46880 [visitado 2019-06-07].

Barberá Gregori, M.A., Blasco Calvo, P., Montoro Sánchez, y Pérez Boullosa, A. (2013). Modelo de calidad de la tutoría de prácticas externas universitarias. En Muñoz Carril, P.C., Raposo-Rivas, M., González Sanmamed, M., Martínez-Figueira, M.E., ZabalzaCerdeiriña, M. y Pérez-Abellás, A. (Coords.) Un Practicum para la formación integral de los estudiantes, (págs. 475-491). Santiago de Compostela: Andavira.

Barberá Gregori, M.A., Pérez Boullosa, A., Chirivella Ramón, A., y García Monteiro, S. (2007). Programa de Evaluación de las Prácticas en Empresas (PAPE) de la Universitat de València. En Cid, A.; Muradás, M.; Zabalza, M.A.; Sanmamed, M.; Raposo, M. e Iglesias, M.L. (Coords.) Actas del IX Symposium Internacional sobre el Practicum: Buenas prácticas en el Practicum (págs. 119-128). Santiago de Compostela: Imprenta Universitaria. Universida de de Santiago de Compostela.

Orden EDU/2346/2011, de 18 de agosto, por la que se establecen las bases reguladoras para la concesión de subvenciones para el Desarrollo de Proyectos y Acciones Orientadas a la Mejora de la Atención Integral y Empleabilidad de los estudiantes universitarios y se procede a su convocatoria para el año 2011. Boletín Oficial del Estado, 1 de septiembre de 2011, págs. 95278-95292. Disponible en "URL": https://www.boe.es/boe/dias/2011/09/01/pdfs/BOE-A-2011-14302.pdf [visitado 202001-23]

Pérez Boullosa, A., Barberá Gregori, M.A. y Chirivella Ramón, A. (2006). Programa d'Avaluació de les Pràctiques en Empreses (PAPE) de la Universitat de València. Guia d'Autoavaluació. València: Universitat de València.

Pérez Boullosa, A., Barberá Gregori, M. A. Chirivella, A. García Monteiro, S. (2009). Programa de Evaluación de las Prácticas en Empresas (PAPE) de la Universitat de València: avance de los primeros resultados. En Raposo Rivas, M., Martínez Figueira, M.E., Lodeiro Enjo, L., Fernández de la Iglesia, J.C., Pérez Abellás, A. (coord.), Actas del X Symposium Internacional sobre el Practicum y las Prácticas en Empresas en la Formación Universitaria: el Practicum más allá del Empleo. Formación Vs Training, (págs. 1045-1062). Santiago de Compostela: Imprenta Universitaria. Universidade de Santiago de Compostela.

Vázquez Navarro, I. (2013). Sistema para la Evaluación y Acreditación de los Tutores de Prácticas Externas de la Universitat de València. En Muñoz Carril, P.C., Raposo-Rivas, M., González Sanmamed, M., Martínez-Figueira, M.E., Zabalza-Cerdeiriña, M. y PérezAbellás, A. (Coords.), Un Practicum para la formación integral de los estudiantes, (págs. 73-84). Santiago de Compostela: Andavira. 
Vázquez Navarro, I., Barberá Gregori, M. A., Blasco Calvo, P., Pérez Boullosa, A., Aracil García, A., Montoro Sánchez, Y. (2013). Cómo tutelar unas prácticas externas de calidad. Manual de Calidad de la tutoría de prácticas externas de la Universitat de València. Valencia: Universitat de València y Fundació Universitat-Empresa, ADEIT. 